\title{
Dampak Kehamilan Tidak Diinginkan terhadap Perawatan Kehamilan dan Bayi (Studi Fenomenologi)
}

\author{
Nawati $^{1}$, Farial Nurhayati ${ }^{2}$ \\ ${ }^{1,2}$ Program Studi Keperawatan Bogor, Politeknik Kesehatan Kemenkes Bandung, Indonesia \\ Email: nawati_sumaryadi@yahoo.co.id
}

\begin{abstract}
Impact of Unwanted Pregnancy on Pregnancy and Baby Care (Phenomenological Study) in Bogor. Unwanted pregnancy was a global social and health challenge. Worldwide 38\% of pregnancies were undesirable pregnancies of 80 million pregnancies per year (Ikamari, 2013). The number of unintended pregnancies in Indonesia was difficult to know and has never been studied in depth either the reason or the attempts made to end the pregnancy. An unwanted pregnancy would have an impact on pregnancy and baby care. Purposes of the study were to determine the effect of unwanted pregnancy on the treatment of pregnancy and infant. The dependent variable of this research was pregnancy and infant care, whereas unwanted pregnancy was an independent variable. This study was a qualitative type of phenomenological study. Data collection used in-depth interview techniques with a reason to get more in-depth information about something that was related to the impact of unwanted pregnancy. The number of respondents based on adequacy and suitability of data. Data analysis techniques were used core analysis. The number of informants in this study was 8 people. The impact of unwanted pregnancy on pregnancy care in this study identified three themes: Themes 1. Psychosocial Problems The Impact of Unwanted Pregnancy, Theme 2 Rejection of Pregnancy and theme 3 Lack of Pregnancy Treatment. While the impact of unwanted pregnancy on infant care identified 1 theme: Need Time to Receive Baby. Hospitals/ Public Health Centres should conduct intensive counseling on mothers with unwanted pregnancies, that is a Family support coaching program.
\end{abstract}

Keywords: Unwanted pregnancy, Care, Pregnancy, Infant

\begin{abstract}
Abstrak: Dampak Kehamilan Tidak Diinginkan terhadap Perawatan Kehamilan dan Bayi (Studi Fenomenologi) di Kota Bogor. Kehamilan tidak diinginkan merupakan tantangan sosial dan kesehatan global. Di seluruh dunia 38\% dari kehamilan merupakan kehamilan tidak diinginkan yaitu 80 juta kehamilan pertahun (Ikamari, 2013). Angka kejadian kehamilan tidak diinginkan di Indonesia sulit diketahui dan belum pernah diteliti secara mendalam baik alasannya atau upaya yang dilakukan untuk mengakhiri kehamilan tersebut. Kehamilan yang tidak diinginkan akan berdampak pada perawatan kehamilan dan bayi. Tujuan penelitian untuk mengetahui dampak kehamilan tidak diinginkan terhadap perawatan kehamilan dan bayi. Variabel dependen penelitian ini yaitu perawatan kehamilan dan bayi, sedangkan kehamilan tidak diinginkan merupakan variabel independen. Penelitian ini jenis kualitatif studi fenomenologi. Pengumpulan data menggunakan teknik wawancara mendalam dengan alasan untuk mendapatkan informasi yang lebih mendalam tentang suatu hal yang berkaitan dengan dampak kehamilan tidak diinginkan. Jumlah responden berdasarkan kecukupan dan kesesuaian data. Teknik analisis data menggunakan analisis inti. Jumlah informan pada penelitian ini adalah 8 orang. Dampak kehamilan yang tidak diinginkan terhadap perawatan kehamilan pada penelitian ini teridentifikasi 3 tema, yaitu: Tema 1. Masalah Psikososial Dampak dari Kehamilan Tidak Diinginkan, Tema 2 Penolakan terhadap Kehamilan dan Tema 3 Kurangnya Perawatan Kehamilan. Sedangkan dampak kehamilan yang tidak diinginkan terhadap perawatan bayi teridentifikasi 1 tema yaitu: Butuh Waktu untuk Menerima Bayi. Diharapkan Rumah sakit/ Puskesmas mengadakan program konseling dengan intensif pada ibu dengan kehamilan tidak diinginkan. Program pembinaan dukungan keluarga terhadap kehamilan tidak diinginkan sangat perlu dilakukan di Puskesmas/ Rumah Sakit.
\end{abstract}

Kata kunci: Kehamilan tidak diinginkan, Perawatan, Kehamilan, Bayi

Kehamilan tidak diinginkan merupakan tantangan sosial dan kesehatan global meliputi kehamilan yang tidak diinginkan (unwanted) dan kehamilan terjadi lebih cepat dari yang direncanakan (mistimed). Di seluruh dunia 38\% dari kehamilan merupakan kehamilan tidak 
diinginkan yaitu 80 juta kehamilan pertahun (Ikamari, 2013). Dampak kehamilan tidak diinginkan akan menimbulkan berbagai permasalahan baik pada bayi maupun bagi keluarganya diantaranya: Anak yang lahir dari masalah diatas dapat mengalami masalah perkembangan mentalnya, terutama jika hingga lahir orang tuanya masih belum dapat menerima. Dampak dari kehamilan tidak diinginkan adalah aborsi. Aborsi yang gagal dapat menyebabkan kerusakan fisik pada bayi dan perdarahan pada ibu.

Emosi ibu mempengaruhi perkembangan anak, emosi yang sangat kuat akan mempengaruhi sistim syaraf otonom, kerja endokrin dan metabolisme sehingga detak jantung dan aktifitas anak akan meningkat, Anak yang lahir dari ibu yang sedih cenderung hiperaktif, jika hal ini tidak segera tertanggulangi maka masalah akan semakin lebih besar lagi dan ibu dapat bersikap kasar dalam merawat bayinya (Elvira, 2001). Angka kejadian kehamilan tidak diinginkan di Indonesia sulit diketahui dan belum pernah diteliti secara mendalam baik alasannya atau upaya yang dilakukan untuk mengakhiri kehamilan tersebut.

Anak-anak yang lahir karena kehamilan yang tidak direncanakan memiliki skor perkembangan yang lebih rendah. Hal ini bisa timbul dari orangtua yang kurang perhatian tetapi juga bisa mencerminkan gangguan dari keadaan sosial ekonomi (Rochebrochard and Joshi, 2013).

Tujuan penelitian ini adalah diketahuinya dampak kehamilan tidak diinginkan terhadap perawatan kehamilan dan diketahuinya dampak kehamilan tidak diinginkan terhadap bayi.

Manfaat penelitian bagi keperawatan maternitas ini untuk lebih memahami tentang kehamilan tidak diinginkan, sehingga dapat lebih menambah wawasan dalam melaksanakan tugas yang berkaitan dengan perawatan kehamilan.

\section{METODE}

Penelitian ini jenis kualitatif studi fenomenologi. Pengumpulan data menggunakan teknik wawancara mendalam dengan alasan untuk mendapatkan informasi yang lebih mendalam tentang suatu hal yang berkaitan dengan alasan ibu tidak menginginkan kehamilannya. Penelitian ini akan dilakukan di Puskesmas dan klinik bidan swasta di Kota Bogor tempat ini dipilih karena pada tempat ini banyak ibu yang datang dengan kehamilan tidak diinginkan.
Informan pada penelitian ini adalah ibu yang hamil yang datang ke puskesmas dan klinik bidan swasta dan mengalami kehamilan tidak diinginkan selama satu tahun terakhir dan dalam status pernikahan yang sah. Cara mendapatkan informan tersebut peneliti meminta informasi dari petugas kesehatan (bidan) sebagai informan kunci, setelah mendapatkan informan untuk memudahkan wawancara peneliti melakukan kunjungan rumah. Penelitian ini melibatkan 8 orang informan yaitu ibu yang tidak menginginkan kehamilannya. Informan diperoleh dari informasi bidan Puskesmas Kota Bogor Tengah. Data diperoleh dari informan dengan menggunakan teknik wawancara mendalam. Data yang diperoleh dari informan diklarifikasi ke keluarga dan petugas Puskesmas.

Data yang telah diringkas kemudian dianalisa, analisa data ini dengan menggunakan analisis inti, dimana ini merupakan proses mengatur urutan data dan mengorganisasikannya ke dalam suatu pola, kategori dan satuan uraian dasar. Hal hal yang akan dilakukan dalam analisis ini antara lain: menelaah kembali informasi yang diperoleh, mengelompokkan berdasarkan topik, mengidentifikasi jawabanjawaban yang sering timbul, mengidentifikasi persamaan dan perbedaan, menganalisis perubahan antar variabel.

\section{HASIL}

Karakteristik informan pada penelitian ini diperoleh data usia informan termuda yaitu 17 tahun, dan usia informan tertua yaitu 44 tahun. Pekerjaan informan terbanyak adalah ibu rumah tangga, beberapa informan bekerja sebagai pelayan, buruh dan Pegawai Negeri Sipil. Pendidikan sebagian besar informan berpendidikan SMA dan SMP. Jumlah anak informan terbanyak memiliki 1 orang anak, dan terbanyak memiliki 5 orang anak.

Dampak kehamilan yang tidak diinginkan terhadap perawatan kehamilan pada penelitian ini teridentifikasi 3 tema, yaitu:

\section{Masalah Psikososial Dampak dari Kehamilan Tidak Diinginkan}

Masalah psikososial dalam keluarga yang tidak siap menerima kehamilan dan bayi adalah faktor internal dari kehamilan tidak diinginkan. Tema ini timbul dari kategorik-kategorik keluhan psikososial, masalah keluarga, masalah mengganggu, masalah psikososial, psikosomatis. Empat orang partisipan mengatakan stres setelah 
mengetahui dirinya hamil dan takut jika keluarga mengetahui kehamilannya.

"Stres, pusing, sakit, tidak mau keluar rumah selama dua bulan setelah tahu bahwa sedang hamil." (I1.L72)

“...Stres, kaget tidak mau hamil,..” (I2,L60)

“......takut tidak mau hamil..” (I3,L42)

\section{Penolakan terhadap Kehamilan}

Keluarga menolak terhadap kehamilan dan menganjurkan tindakan mengakhiri kehamilan merupakan masalah dampak kehamilan yang tidak dinginkan terhadap lingkungan atau keluarga. Tema ini timbul dari kategorik menolak kehamilan, keluarga tidak menginginkan kehamilan , umur sudah tua, anak banyak, belum nikah,marah, membenci. Tujuh informan mengatakan keluarga menolak kehamilan.

"...keluarga kaget, marah suruh menggugurkan ...” (I2,L54)

"...marah, mertua sampai sekarang ga mau gendong cucunya katanya bukan cucunya dia.." (I3,L56)

"...keluarga marah marah setelah tau hamil..." (I5,L51)

“...orang tua menganjurkan untuk digugurkan dengan minum jamu, dipijit ke paraji dan disuruh naek turun tangga.." (I7,L49)

\section{Kurangnya Perawatan Kehamilan}

Tema ini diperoleh dari kategorik tidak periksa kehamilan secara rutin, lupa karena sering berganti tempat periksanya, malas, makan seadanya karena keluhan psikosomatik, minum obat obatan , jamu untuk haid, dipijat, jamu pelancar haid, tidak memakai khusus baju hamil. Informan sebagian besar mengatakan tidak memeriksa kehamilan secara rutin dan berusaha untuk mengakhiri kehamilannya.

"..Tidak rutin baru tahu hamil setelah 5 bulan, diperiksa ke puskesmas..” (I1,L95)

“...ga pernah periksa hanya sekali karena disuruh paraji, periksa ke bidan disuruh usg ke dokter, hasilnya perempuan katanya, saya tambah malas dan tidak mau datang lagi ..."(I4,L84)

“...minum obat pelancar haid jamu
Sedangkan dampak kehamilan yang tidak diinginkan terhadap perawatan bayi teridentifikasi 1 tema yaitu :

\section{Butuh Waktu untuk Menerima Bayi}

Tema ini diperoleh dari kategorik: tidak ada yang langsung menyusui, alasan tidak keluar ASI, bayi diberi susu formula dan bubur, sejak bayi lahir langsung diberi makanan, menyayangi bayi, tidak ada persiapan khusus, tidak mengetahui jenis immunisasi yang sudah diberikan, pertumbuhan dan perkembangannya lebih lambat. Sebagian besar informan mengatakan tidak langsung menyusui bayinya Karena air susu tidak keluar.

“....Tidak pakai ASI, langsung formula dan bubur bayi karena nangis melulu.. "(I1,L107)

“....Selama seminggu ga nyusui..” (I3,L103)

\section{PEMBAHASAN}

Masalah psikososial dalam keluarga yang tidak siap menerima kehamilan dan bayi adalah faktor internal dari kehamilan tidak diinginkan. Hal ini sesuai dengan penelitian kualitatif dari Izugbara \& Carolyne Egesa (2014) partisipan melaporkan merasa takut, marah, dan putus asa saat mengetahui bahwa mereka telah hamil secara tidak sengaja: "Ketika saya tahu, saya sangat ketakutan, saya hampir bunuh diri, saya tidak tahu harus memulai dari mana,". Data yang dikumpulkan menunjukkan bahwa menanggapi wanita menyalahkan diri mereka sendiri atas kehamilan yang tidak diinginkan. Hasil penelitian kualitatif Widyoningsih (2011) menghasilkan tema stres yang dirasakan keluarga. Dalam penelitian tersebut teridentifikasi adanya stres yang dirasakan keluarga, meliputi stres fisik, stres finansial, stres psikologis dan stres sosial.

Rendahnya tingkat pendidikan dan sosial ekonomi, lamanya menikah, dan ketidakinginan pasangan terhadap kehamilan adalah faktor risiko dari kehamilan tidak diinginkan. Wanita dengan kehamilan tidak diinginkan berisiko tinggi terhadap perilaku tidak sehat, tidak merawat kehamilan dan memiliki risiko tinggi terhadap aborsi (Shiadeh, et al, 2016).

Secara umum perasaan yang muncul dari remaja, orang tua, dan pasangan terhadap kehamilan adalah perasaan tidak menyenangkan. Pandangan remaja terkait kehamilannya adalah bahwa kehamilan terjadi dikarenakan pergaulan yang menuntun remaja untuk melakukan hubungan seksual pranikah. Kehamilan remaja 
berdampak bagi remaja itu sendiri dan anak yang dilahirkan. Dukungan pada saat kehamilan dan perawatan anak datang dari orang tua dan teman. Status hubungan dengan pasangan mempengaruhi perilaku perawatan kesehatan (Ratnaningrum, 2016).

Mengabaikan perawatan kehamilan dan pada awal kehamilan ada usaha untuk mengakhirinya. Ibu yang mengalami kehamilan tidak diinginkan berpeluang tidak melakukan perawatan kehamilan 1,79 dibandingkan kehamilan diinginkan; berpeluang sama terhadap perilaku tidak memberikan ASI eksklusif dan tidak memberikan imunisasi dasar lengkap. Hasil analisis stratifikasi menunjukkan pengaruh status kehamilan tidak diinginkan terhadap perilaku: perawatan kehamilan; pemberian ASI eksklusif dan pemberian imunisasi dasar lengkap yang juga dipengaruhi oleh status ekonomi. Semakin kaya cenderung melakukan perawatan (Dini, et al, 2016).

Seorang responden mengatakan bahwa kehamilannya hasil dari perbuatan seksual cobacoba, namun ternyata hal tersebut menyebabkan kehamilan. Wanita memandang kehamilan sebagai suatu hasil alami hubungan perkawinan baik diinginkan maupun tidak diinginkan tergantung dari keadaan. Pada remaja kehamilan terjadi akibat percobaan seksual. Setelah kehamilan dipastikan respon emosi wanita dapat bervariasi, dari yang sangat gembira sampai syok, tidak yakin dan putus asa. Reaksi yang diperlihatkan pada banyak wanita nanti atau tidak sekarang (Bobak, et al, 2005).

Informan sebagian besar mengatakan pernah melakukan perbuatan akan mengakhiri kehamilannya dengan berbagai cara. Wanita yang bahagia dengan kehamilannya dari waktu ke waktu dapat memiliki sikap bermusuhan terhadap kehamilan atau janinnya. Pernyataan pasangan tentang kecantikan wanita yang tidak hamil atau peristiwa promosi seorang kolega ketika keputusan memiliki seorang anak berarti melepaskan pekerjaan dapat meningkatkan rasa ambivalensi. Perasaan ambivalen yang menetap sampai trimester tiga dapat mengindikasikan

\section{DAFTAR PUSTAKA}

Bobak, Lowdermilk, Jensen. 2005. Buku Ajar Keperawatan Maternitas/ Maternity Nursing.Alih Bahasa Maria A. Wijayarini. Peter I. Anugerah, edisi 4. Jakarta: EGC. bahwa konflik peran sebagai ibu belum diatasi (Bobak, et al, 2005).

Kehamilan melahirkan di luar nikah dan kehamilan yang tidak diinginkan dikaitkan dengan berbagai hasil yang merugikan untuk ibu dan anakanak mereka. Anak-anak yang lahir di luar nikah lebih cenderung memburuk, termasuk prestasi sekolah, perkembangan sosial dan emosional, kesehatan, dan kesuksesan mereka di pasar tenaga kerja. Anak-anak ini juga berisiko lebih besar mengalami pelecehan dan penolakan dari orang tua (terutama dari pasangan ibu mereka yang bukan ayah biologis mereka), dan kecenderungan menjadi orang tua dini, tidak lulus dari sekolah menengah atau perguruan tinggi (Waldfogel, Craigie, dan Brooks-Gunn, 2010). Anak-anak dari kehamilan yang tidak diinginkan lebih cenderung memiliki kesehatan fisik atau mental yang buruk dan lebih mungkin untuk terlibat perilaku nakal selama masa remaja, bahkan mengendalikan karakteristik keluarga (Logan et al., 2007).

\section{SIMPULAN}

Dampak kehamilan yang tidak diinginkan terhadap perawatan kehamilan pada penelitian ini teridentifikasi 3 tema, yaitu: tema 1. masalah psikososial dampak dari kehamilan tidak diinginkan; tema 2 . penolakan terhadap kehamilan; dan tema 3. kurangnya perawatan kehamilan. Sedangkan dampak kehamilan yang tidak diinginkan terhadap perawatan bayi teridentifikasi 1 tema yaitu: butuh waktu untuk menerima bayi.

\section{SARAN}

Diharapkan Rumah sakit/Puskesmas mengadakan program konseling yang intensif pada ibu dengan kehamilan tidak diinginkan untuk mempersiapkan diri dalam merawat kehamilan dan bayinya. Program pembinaan dukungan keluarga terhadap kehamilan tidak diinginkan sangat perlu dilakukan di Puskesmas/ Rumah Sakit.

Bagi Instansi Pendidikan Dapat menjadi dasar pemikiran atau data dasar bagi penelitian selanjutnya tentang kehamilan tidak diinginkan.

Dini, L. I., Riono, P., \& Sulistiyowati, N. 2016. Pengaruh Status Kehamilan Tidak Diinginkan Terhadap Perilaku Ibu Selama Kehamilan dan Setelah Kelahiran Di Indonesia (Analisis Data SDKI 
2012). Jurnal

Reproduksi, 7(2), 119-133.

Elvira, D Sylvia. 2001. Tinjauan Psikologi pada Kehamilan Tidak Diinginkan. Seminar Gerakan Sayang Kehidupan. Jakarta.

Ikamari, L., Izugbara, C., \& Ochako, R. 2013. Prevalence and determinants of unintended pregnancy among women in Nairobi, Kenya. BMC pregnancy and childbirth, 13(1), 69.

Izugbara, Chimaraoke, Carolyne Egesa. 2014. The Management of Unwanted Pregnancy Among Woman in Nairobi, Kenya. International Journal of Sexual Health, 26:100-112, 2014.

Logan, Cassandra, Emily Holcombe, Jennifer Manlove, and Suzanne Ryan. 2007. The consequences of Unintended Childbearing: A White Paper. Washington: Child Trends.

Ratnaningrum, D., Nisman, W. A., Kep, S., Lusmilasari, L., \& Kp, S. 2016. Gambaran Perilaku Perawatan Kehamilan pada Kehamilan Remaja Di Kabupaten Sleman, Yogyakarta. [Disertasi]. Yogyakata: Universitas Gadjah Mada.
Rochebrochard. Elise de La., Joshi. Heather 2013. Children Born After Unplanned Pregnancies and Cognitive Development at 3 Years: Social Differentials in the United Kingdom Millennium Cohort. Am $J$ Epidemiol. Sep 15; 178(6): 910-920.

Shiadeh, Malihe Nourollahpour Shiadeh, Nourossadat Kariman, Maryam Bakhtiari, Samaneh Mansouri, Saeed Mehravar. 2016. Unwanted Pregnancy and Its Risk Factors Among Pregnant Women in Tehran, Iran. Nurse Midwifery Study. September; 5(3):e29740.

Waldfogel, Jane, Terry-Ann Craigie, and Jeanne Brooks-Gunn. 2010. "Fragile Families and Child Wellbeing." The Future of Children, 20 (2): 87.

Widyoningsih. 2011. Pengalaman Keluarga Merawat Anak Remaja dengan Kehamilan Tidak Diinginkan (KTD) Di Kabupaten Cilacap Provinsi Jawa Tengah: Studi Fenomenologi. [Tesis]. Jakarta: Magister Keperawatan Fakultas Ilmu Keperawatan. Universitas Indonesia. 